\title{
ANALISIS PERBANDINGAN KINERJA KEUANGAN MENGGUNAKAN METODE CAMEL PADA BANK BRI DAN BANK BNI PERIODE 2011-2015
}

\author{
Angelita Chyntia Kalendesang ${ }^{1}$, Sifrid S. Pangemanan ${ }^{2}$, Natalia Y. T. Gerungai ${ }^{3}$ \\ ${ }^{1}$ Jurusan Akuntansi, Fakultas Ekonomi dan Bisnis, Universitas Sam Ratulangi, Jl. Kampus Bahu, Manado, \\ 95115, Indonesia \\ ${ }^{2}$ Jurusan Akuntansi, Fakultas Ekonomi dan Bisnis, Universitas Sam Ratulangi, Jl. Kampus Bahu, Manado, \\ 95115, Indonesia \\ ${ }^{3}$ Jurusan Akuntansi, Fakultas Ekonomi dan Bisnis, Universitas Sam Ratulangi, Jl. Kampus Bahu, Manado, \\ 95115, Indonesia \\ E-mail : angelitakalendesang@gmail.com
}

\begin{abstract}
Bank as an intermediary institutions play a very important role in a country's economy. Therefore, the existence of a healthy bank is necessary, in order to achieve that goals banks have to be very careful in running their business and they also need special supervision include control from government through Central Bank which is known as Bank Indonesia. This research aims to examine and analyze the Assessment of the level of health of Commercial Bank, based on Bank Indonesia Regulation No. 13/1 / PBI / 2011, by using CAMEL (Capital, Asset, Management, Earnings, Liquidity) as its benchmarking tools. The ratio used includes financial ratio analysis such as CAR, KAP, NPM, ROA, BOPO and LDR. The object of study includes government-owned public banks listed on the IDX representing the entire population, but samples only taken from the financial statements of Bank BRI and Bank BNI during fiscal year 2011-2015, through research method of comparison of descriptive analysis to financial performance at both Bank (BRI \& BNI), it can be concluded whether both of them are in the predicate healthy, healthy enough, less healthy or unhealthy. The results showed that both banks are equally healthy, while BRI have had better improvement of financial performance compared to BNI.
\end{abstract}

Key words : Financial Performance, Financial Ratio, CAMEL Method, Commercial Bank Health.

\section{PENDAHULUAN}

Pada saat ini dalam perekonomian telah tumbuh dan berkembang berbagai macam lembaga keuangan. Salah satu di antara lembaga-lembaga keuangan tersebut yang nampaknya paling besar dalam perekonomian adalah lembaga keuangan bank, yang disebut bank. Bank merupakan perusahaan jasa yang menyediakan jasa keuangan bagi seluruh lapisan masyarakat. Baik badan-badan pemerintah, swasta maupun perorangan yang menyimpan dana. Menurut Kasmir (2012:12) Bank adalah lembaga keuangan yang kegiatan utamanya adalah menghimpun dana dari masyarakat dan menyalurkannya kembali dana tersebut ke masyarakat serta memberikan jasa lainnya.

Di Indonesia banyak kita jumpai jenis-jenis bank, diantaranya adalah bank milik negara, bank swasta nasional, dan bank asing. Bank umum milik negara memiliki peran ganda yaitu keuntungan (profit oriented) dan agen pembangunan negara (social oriented). Oleh karena itu, bank milik negara dituntut agar dapat mengelola asset negara dengan baik. Ada beberapa bank umum milik negara di Indonesia, diantaranya adalah Bank Mandiri, Bank BTN, Bank Rakyat Indonesia (BRI) dan Bank Negara Indonesia (BNI). Dari keempat bank tersebut bank BRI dan bank BNI merupakan bank yang sangat di kenal masyarakat karena kedua bank ini memiliki banyak cabang dan dapat di temui di berbagai daerah di Indonesia. 
Kesehatan suatu bank adalah kemampuan suatu bank untuk melakukan kegiatan operasional bank secara normal dan mampu memenuhi semua kewajibannya dengan baik berdasarkan cara-cara yang sesuai dengan peraturan perbankan yang berlaku (Darmawi 2011:210). Kesehatan suatu bank merupakan kepentingan semua pihak yang terkait baik pemilik, pengelola bank, masyarakat, pengguna jasa bank dan Bank Indonesia selaku otoritas pengawasan bank. Suatu sistem perbankan dalam kondisi yang tidak sehat akan menyebabkan fungsi bank sebagai lembaga intermediasi tidak akan berfungsi dengan optimal. Terganggunya fungsi intermediasi maka alokasi dan penyediaan dana dari perbankan untuk kegiatan investasi dan membiayai dalam perekonomian menjadi terbatas.

Oleh karena itu sebuah bank memerlukan analisis untuk mengetahui kondisinya setelah melakukan kegiatan operasional dalam jangka waktu tertentu. Analisis yang dilakukan adalah berupa penilaian tingkat kesehatan bank. Bank Indonesia dan bank yang ada di Indonesia memiliki metode untuk menilai tingkat kesehatan bank yang dinamakan metode CAMEL (Capital, Assets, Management, Earnings dan Liquidity), aspek-aspek tersebut menggunakan rasio-rasio keuangan. Dimana metode ini menghitung rasio-rasio capital dengan menggunakan rasio capital adequacy ratio (CAR), assets dengan menggunakan rasio kualitas aktiva produktif (KAP), management menggunakan rasio net profit margin (NPM), earnings menggunakan rasio return on assets (ROA), dan biaya operasional terhadap pendapatan operasional (BOPO), dan liquidity dengan menggunakan rasio loan to deposit ratio (LDR) yang pada akhirnya akan terlihat tingkat kesehatan suatu bank berdasarkan kriteria yang ditetapkan dalam Peraturan Bank Indonesia Nomor 13/1/PBI/2011 tentang Penilaian Tingkat Kesehatan Bank Umum. Maka penulis tertarik untuk melakukan penelitian mengenai "Analisis perbandingan kinerja keuangan menggunakan metode CAMEL pada Bank BRI dan Bank BNI periode 2011-2015”.

\section{TINJAUAN PUSTAKA}

\subsection{Laporan Keuangan}

Menurut PSAK No. 1 (2015: 1), "Laporan keuangan adalah penyajian terstruktur dari posisi keuangan dan kinerja keuangan suatu entitas". Laporan ini menampilkan sejarah entitas yang dikuantifikasi dalam nilai moneter.

Menurut Pernyataan Standar Akuntansi Keuangan (PSAK) No. 1 paragraf 08, 09, 10, 11 dan 12 (IAI, 2015) laporan keuangan yang lengkap terdiri dari:

a) Laporan posisi keuangan pada akhir periode;

b) Laporan laba rugi komprehensif selama periode;

c) Laporan perubahan ekuitas selama periode;

d) Laporan arus kas selama periode;

e) Catatan atas laporan keuangan, berisi ringkasan kebijakan akuntansi penting dan informasi penjelasan lainnya; dan

f) Laporan posisi keuangan pada awal periode komparatif yang disajikan ketika entitas menerapkan suatu kebijakan akuntansi secara retrospektif atau membuat penyajian kembali pos-pos laporan keuangan, atau ketika entitas mereklasifikasi pos-pos dalam laporan keuangannya.

\subsection{Tujuan Laporan Keuangan}

Hery (2016:4) menyatakan tujuan laporan keuangan adalah untuk memberikan informasi yang berguna bagi investor dan kreditor dalam pengambilan keputusan investasi dan kredit. Jelasnya adalah laporan keuangan mampu memberikan informasi keuangan pada pihak dalam dan luar perusahaan yang memiliki kepentingan terhadap perusahaan.

\subsection{Kinerja Keuangan}


Kinerja (performance) dalam kamus istilah akuntansi adalah kuantifikasi dari keefektifan dalam pengoperasian bisnis selama periode tertentu. Fahmi (2014:2) menyatakan kinerja keuangan merupakan gambaran dari pencapaian keberhasilan perusahaan dapat diartikan sebagai hasil yang telah dicapai atas berbagai aktivitas yang telah dilakukan.

\subsection{Bank}

Dalam buku "Bank dan lembaga keuangan lainnya" Kasmir (2014:24) Menurut undang-undang RI Nomor 10 tahun 1998 tanggal 10 November 1998 tentang perbankan, yang dimaksud dengan Bank adalah badan usaha yang menghimpun dana dari masyarakat dalam bentuk simpanan dan menyalurkannya kepada masyarakat dalam bentuk kredit atau bentuk dan atau bentuk-bentuk lainnya dalam rangka meningkatkan taraf hidup rakyat banyak.

\subsection{Metode CAMEL}

Dalam Kasmir (2014:44-46) menyatakan Penilaian untuk menentukan kondisi suatu bank biasanya menggunakan metode analisis CAMEL.

1. Capital (Permodalan)

Yang dinilai adalah permodalan yang ada didasarkan kepada Kewajiban Penyediaan Modal Minimum (KPMM) bank, dan Aktiva Tertimbang Menurut Risiko merupakan penjumlahan dari aktiva menurut risiko kredit + aktiva menurut risiko operasional + aktiva menurut risiko pasar. Penilaian tersebut didasarkan kepada CAR (Capital Adequacy Ratio) yang telah ditetapkan BI.

$\mathrm{CAR}=\longrightarrow \times 100 \%$

Tabel 1. kriteria penilaian Capital Adequacy Ratio (CAR)

\begin{tabular}{cc}
\hline Nilai CAR & Predikat \\
\hline$>8 \%$ & Sehat \\
$7,9-8 \%$ & Cukup sehat \\
$6,5-, 7,9 \%$ & Kurang sehat \\
$<6,5 \%$ & Tidak sehat \\
\hline
\end{tabular}

Sumber : Lukman Dendawijaya 2009

2. Asset (Aktiva)

Aktiva suatu bank akan dinilai berdasarkan kualitas aktiva produktif (KAP) yang diklasifikasikan adalah aktiva produktif, baik yang sudah maupun yang mengandung potensi tidak memberikan penghasilan atau menimbulkan kerugian yang besarnya ditetapkan sebagai berikut:

a. $25 \%$ dari kredit yang digolongkan Dalam Perhatian Khusus (DPK)

b. $50 \%$ dari kredit yang digolongkan Kurang Lancar (KL)

c. $75 \%$ dari kredit yang digolongkan Diragukan (D)

d. $100 \%$ dari kredit yang digolongkan Macet (M)

$\mathrm{KAP}=\longrightarrow \times 100 \%$ 
Tabel 2. kriteria penilaian Kualitas Aktiva Produktif (KAP)

\begin{tabular}{cc}
\hline Nilai KAP & Predikat \\
\hline$<10,35 \%$ & Sehat \\
$10,35-12,60 \%$ & Cukup sehat \\
$12,61-14,85 \%$ & Kurang sehat \\
$>14,86 \%$ & Tidak sehat \\
\hline
\end{tabular}

Sumber : Lukman Dendawijaya 2009

3. Management (Manajemen)

Penilaian terhadap faktor manajemen berdasarkan Peraturan Bank Indonesia Nomor 13/1/PBI/2011 yaitu meliputi:
a. Manajemen umum
b. Manajemen risiko
c. Kepatuhan bank

$\mathrm{NPM}=$ $\mathrm{x} 100 \%$

4. Earnings (Rentabilitas)

Rentabilitas merupakan aspek untuk mengukur kemampuan bank dalam meningkatkan labanya apakah, setiap periode atau untuk mengukur tingkat efisiensi profitabilitas yang dicapai bank yang bersangkutan. Bank yang sehat adalah bank yang di ukur secara rentabilitas yang terus meningkat. Penilaian juga dilakukan dengan:

a. Rasio laba terhadap total asset (ROA)

b. Perbandingan biaya operasi dan pendapatan operasi (BOPO)

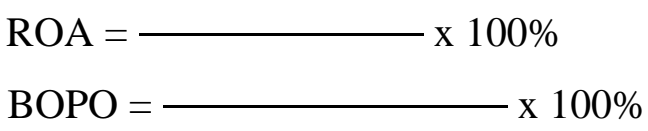

Tabel 3. kriteria penilaian Return On Asset (ROA)

\begin{tabular}{ccc}
\hline Nilai ROA & Nilai BOPO & Predikat \\
\hline$>1,22 \%$ & $<93,52 \%$ & Sehat \\
$0,99-1,21 \%$ & $93,52-94,73 \%$ & Cukup sehat \\
$0,77-0,98 \%$ & $94,73 \%-95,92 \%$ & Kurang sehat \\
$<0,76 \%$ & $>95,92 \%$ & Tidak sehat \\
\hline
\end{tabular}

Sumber : Lukman Dendawijaya 2009

5. Liquidity (Likuiditas)

Dalam Pandia (2012:113) likuiditas adalah kemampuan bank untuk memenuhi kewajiban jangka pendek. Suatu bank di anggap likuid apabila bank tersebut memiliki kesanggupan untuk membayar penarikan, giro, tabungan, deposito berjangka, pinjaman bank yang segera jatuh tempo, pemenuhan permintaan kredit tanpa adanya suatu penundaan.

Aspek likuiditas yang dinilai dalam analisis CAMEL ini adalah rasio kredit terhadap dana pihak ketiga

$$
\mathrm{LDR}=\longrightarrow \times 100 \%
$$


Tabel 4. kriteria penilaian Loan to Deposito Ratio (LDR)

\begin{tabular}{cc} 
Nilai LDR & Predikat \\
$<94,75 \%$ & Sehat \\
$94,75-98,75 \%$ & Cukup sehat \\
$98,75-102,25 \%$ & Kurang sehat \\
$>102,25 \%$ & Tidak sehat \\
\hline
\end{tabular}

Sumber : Lukman Dendawijaya 2009

Ketentuan Bank Indonesia bahwa kategori sehat dapat dilihat pada tabel berikut ini:

Tabel 5. Tingkat kesehatan bank menurut CAMEL

\begin{tabular}{cc}
\hline Nilai KAP & Predikat \\
\hline $81-100 \%$ & Sehat \\
$66-81 \%$ & Cukup sehat \\
$51-66 \%$ & Kurang sehat \\
$0-51 \%$ & Tidak sehat \\
\hline
\end{tabular}

Sumber: Pandia Frianto 2012

\subsection{Penelitian Terdahulu}

1. Penelitian Fitria (2016) berdasarkan hasil perhitungan rasio-rasio keuangan sesuai pada komponen dalam metode CAMEL pada PT Bank Negara Indonesia, Tbk, dan entitas anak dengan PT Bank Internasional Indonesia, Tbk dan entitas anak dari tahun 2010-2014, PT Bank Negara Indonesia, Tbk, dan entitas anak dengan PT Bank Internasional Indonesia, Tbk dan entitas anak adalah bank yang sehat.

2. Penelitian yang dilakukan Jeremiah (2013) hasil penelitiannya menunjukkan terdapat 3 Bank yaitu Bank Mandiri,Bank BNI dan Bank BRI mendapatkan predikat sehat sedangkan 1 Bank yaitu Bank BTN mendapatkan predikat cukup sehat.

\section{METODE PENELITIAN}

\subsection{Jenis dan Sumber Data}

Jenis data yang digunakan adalah data kuantitatif atau data dengan uraian angkaangka yaitu berupa laporan keuangan dari perusahaan perbankan yang telah dipublikasikan. Periode laporan tersebut per 31 desember 2011 sampai dengan 31 desember 2015 dan data ini diperlukan untuk membentuk proksi rasio keuangan. Sumber data yang digunakan dalam penelitian ini adalah data sekunder berupa dokumentasi laporan keuangan perbankan dari bursa efek Indonesia yaitu bank BRI dan bank BNI.

\subsection{Metode Analisis Data}

Metode yang dipakai dalam penelitian ini adalah metode analisis deskriptif komparatif, ialah menjelaskan hasil penelitian yang berupa data -data laporan keuangan yang berhubungan dengan kinerja keuangan bank, untuk membandingkan tingkat kesehatan antara Bank BRI dan Bank BNI. Dan alat analisis yang digunakan adalah rasio keuangan.

\section{HASIL ANALISIS DAN PEMBAHASAN}

\subsection{Hasil Analisis}

Capital (Permodalan)

\section{- Hasil Perhitungan Capital Adequacy Ratio (CAR)}

Yang dinilai adalah permodalan yang ada didasarkan kepada Kewajiban Penyediaan Modal Minimum (KPMM) bank, dan Aktiva Tertimbang Menurut Risiko merupakan 
penjumlahan dari aktiva menurut risiko kredit + aktiva menurut risiko operasional + aktiva menurut risiko pasar.

Tabel 6. Hasil Perhitungan CAR pada Bank BNI dan Bank BRI tahun 2011 - 2015

\begin{tabular}{ccccc}
\hline Nama Perusahaan & Tahun & Modal (Jutaan Rupiah) & ATMR (Jutaan Rupiah) & CAR (\%) \\
\hline & 2011 & $32,691,914$ & $185,403,030$ & 17.63 \\
PT. Bank Negara & 2012 & $39,190,799$ & $235,143,102$ & 16.66 \\
Indonesia (BNI) & 2013 & $43,563,420$ & $288,616,781$ & 15.09 \\
& 2014 & $50,352,050$ & $310,485,402$ & 16.22 \\
& 2015 & $73,799,000$ & $378,565,000$ & 19.49 \\
\hline & 2011 & $41,815,988$ & $279,602,642$ & 14.96 \\
PT. Bank Rakyat & 2012 & $55,133,677$ & $325,352,028$ & 16.95 \\
Indonesia (BRI) & 2013 & $69,472,036$ & $408,858,393$ & 16.99 \\
& 2014 & $85,706,557$ & $468,182,076$ & 18.31 \\
& 2015 & $110,580,617$ & $537,070,938$ & 20.59 \\
\hline
\end{tabular}

Sumber: data diolah Mei 2017

Rasio CAR dikatakan sehat jika berada pada $>8 \%$. Dari perhitungan diatas dapat disimpulkan bahwa Bank BNI dan Bank BRI berada pada predikat SEHAT, karena dari hasilnya CAR kedua bank ini $>8 \%$. Ini menunjukkan bahwa tingkat kesehatan kedua bank ini sudah sangat baik dalam pemenuhan kecukupan modal.

\section{Asset (Aktiva)}

- Perhitungan Kualitas Aktiva Produktif (KAP)

Kualitas Aktiva Produktif dalam hal ini menilai jenis - jenis aktiva yang dimiliki oleh bank dan harus diketahui juga jumlah masing - masing Aktiva Produktif (AP) dan Aktiva Produktif yang Diklasifikasikan. Jumlah aktiva produktif dan aktiva produktif yang diklasifikasikan dapat dilihat pada tabel berikut:

Tabel 7. Hasil perhitungan Kualitas Aktiva Produktif (KAP) pada Bank BNI dan Bank BRI tahun 2011 - 2015

\begin{tabular}{ccccc}
\hline Nama Perusahaan & Tahun & APYD (Jutaan rupiah) & AP (Jutaan rupiah) & KAP (\%) \\
\hline & 2011 & $6,685,150$ & $437,254,055$ & 1.52 \\
PT. Bank Negara & 2012 & $17,488,479$ & $523,450,398$ & 3.34 \\
Indonesia (BNI) & 2013 & $16,238,654$ & $635,489,165$ & 2.55 \\
& 2014 & $15,652,651$ & $657,152,488$ & 2.38 \\
& 2015 & $36,640,988$ & $1,340,029,257$ & 2.73 \\
\hline & 2011 & $11,641,237$ & $435,050,133$ & 2.68 \\
PT. Bank Rakyat & 2012 & $11,411,819$ & $533,315,288$ & 2.14 \\
Indonesia (BRI) & 2013 & $12,557,601$ & $643,286,920$ & 1.95 \\
& 2014 & $18,787,100$ & $767,286,920$ & 2.45 \\
& 2015 & $20,642,212$ & $882,871,169$ & 2.34 \\
\hline
\end{tabular}

Sumber: data diolah Mei 2017

Rasio KAP dapat dikatakan sehat jika berada pada $<10,35 \%$. Dari hasil KAP Bank BNI dan Bank BRI diatas menunjukkan bahwa kedua Bank berada pada predikat SEHAT, karena masing - masing nilai dari kedua bank berada $<10,35 \%$. Karena semakin kecil nilai 
KAP yang diperoleh, maka menunjukkan bahwa kinerja bank dalam menjaga kualitas aktiva produktif sudah sangat baik.

\section{Management (Manajemen)}

- Perhitungan Net Profit Margin (NPM)

Tabel 8. Hasil Perhitungan Net Profit Margin (NPM) pada Bank BNI dan Bank BRI tahun 2011 - 2015

\begin{tabular}{ccccc}
\hline Nama Perusahaan & Tahun & $\begin{array}{c}\text { Laba Bersih } \\
\text { (Jutaan Rupiah) }\end{array}$ & $\begin{array}{c}\text { Pendapatan Operasional } \\
\text { (Jutaan Rupiah) }\end{array}$ & NPM (\%) \\
\hline & 2011 & $5,779,209$ & $25,891,684$ & 22.32 \\
PT. Bank Negara & 2012 & $6,792,072$ & $28,765,115$ & 23.61 \\
Indonesia (BNI) & 2013 & $8,881,963$ & $33,426,726$ & 26.57 \\
& 2014 & $10,515,588$ & $42,009,837$ & 25.03 \\
& 2015 & $9,141,000$ & $35,258,000$ & 25.91 \\
\hline & 2011 & $15,082,939$ & $52,866,160$ & 28.53 \\
PT. Bank Rakyat & 2012 & $18,520,950$ & $56,090,675$ & 33.02 \\
Indonesia (BRI) & 2013 & $21,160,150$ & $65,614,918$ & 32.25 \\
& 2014 & $24,197,254$ & $81,643,689$ & 29.64 \\
& 2015 & $25,410,788$ & $73,115,100$ & 34.75 \\
\hline
\end{tabular}

Sumber: data diolah Mei 20017

Berdasarkan hasil dari perhitungan NPM Bank BNI dan Bank BRI diatas mengalami fluktuasi, namun rasio NPM dari kedua bank masih berada pada predikat SEHAT. Semakin tinggi nilai NPM maka menunjukkan semakin baik kegiatan manajemen pengaturan dan operasi di masing - masing bank tersebut.

\section{Earnings (Rentabilitas)}

- Perhitungan Return On Asset (ROA) dan Beban Operasional Pendapatan Operasional (BOPO)

Rentabilitas merupakan aspek untuk mengukur kemampuan bank dalam meningkatkan labanya.

Tabel 9. Hasil perhitungan Return On Asset (ROA) pada Bank BNI dan Bank BRI tahun 2011 - 2015

\begin{tabular}{ccccc}
\hline Nama Perusahaan & Tahun & $\begin{array}{c}\text { Laba Sebelum Pajak } \\
\text { (Jutaan Rupiah) }\end{array}$ & $\begin{array}{c}\text { Total Aktiva (Jutaan } \\
\text { Rupiah) }\end{array}$ & ROA (\%) \\
\hline & 2011 & $7,182,546$ & $258,950,726$ & 2.77 \\
PT. Bank Negara & 2012 & $8,600,811$ & $301,683,071$ & 2.85 \\
Indonesia (BNI) & 2013 & $11,056,411$ & $337,909,510$ & 3,27 \\
& 2014 & $13,097,584$ & $393,466,072$ & 3,33 \\
& 2015 & $11,466,000$ & $508,595,000$ & 2.25 \\
\hline & 2011 & $18,731,302$ & $395,977,564$ & 4.73 \\
PT. Bank Rakyat & 2012 & $23,638,833$ & $479,941,488$ & 4.93 \\
Indonesia (BRI) & 2013 & $27,647,876$ & $556,448,391$ & 4,97 \\
& 2014 & $30,770,208$ & $669,737,264$ & 4.59 \\
& 2015 & $32,494,018$ & $878,426,312$ & 3.69 \\
\hline
\end{tabular}

Sumber: data dilah Mei 2017 
Rasio ROA dikatakan sehat jika hasil perhitungannya berada pada $>1,22 \%$. Berdasakan hasil perhitungan kedua bank diatas menunjukkan bahwa bank BNI dan bank BRI berada pada predikat SEHAT, karena kedua bank memperoleh hasil $>1,22 \%$. Kedua bank juga memiliki kesamaan pada tahun 2015 karena mengalami penurunan, namun tetap berada pada predikat sehat, hal tersebut menyatakan bahwa kedua bank masing - masing mampu dalam menciptakan laba dengan baik tiap tahun.

Tabel 10. Hasil perhitungan Beban Operasional Pendapatan Operasional pada Bank BNI dan Bank BRI tahun 2011 - 2015

\begin{tabular}{ccccc}
\hline Nama Perusahaan & Tahun & $\begin{array}{c}\text { Total Beban } \\
\text { Operasional (Jutaan } \\
\text { Rupiah) }\end{array}$ & $\begin{array}{c}\text { Total Pendapatan } \\
\text { Operasional (Jutaan } \\
\text { Rupiah) }\end{array}$ & $\begin{array}{c}\text { BOPO } \\
(\%)\end{array}$ \\
\hline & 2011 & $19,009,138$ & $25,891,684$ & 73.42 \\
PT. Bank Negara & 2012 & $20,421,302$ & $28,765,115$ & 70.99 \\
Indonesia (BNI) & 2013 & $22,451,395$ & $33,426,726$ & 67.17 \\
& 2014 & $29,315,559$ & $42,009,837$ & 69.78 \\
& 2015 & $26,619,700$ & $35,358,000$ & 75.29 \\
\hline & 2011 & $35,255,125$ & $52,866,160$ & 66.69 \\
PT. Bank Rakyat & 2012 & $33,614,352$ & $56,090,675$ & 59.93 \\
Indonesia (BRI) & 2013 & $39,750,066$ & $65,614,918$ & 60.58 \\
& 2014 & $53,368,052$ & $81,643,689$ & 65.37 \\
& 2015 & $49,689,022$ & $73,115,100$ & 67.96 \\
\hline
\end{tabular}

Sumber: data diolah Mei 2017

Rasio BOPO dikatakan sehat jika berada pada $<93,52 \%$. Dari perhitungan kedua bank diatas menunjukkan bahwa bank BNI dan bank BRI berada pada predikat SEHAT. Berdasarkan hasil diatas menyatakan bahwa pendapatan operasional yang diperoleh sudah baik sehingga mampu menutupi beban operasional yang dikeluarkan oleh bank.

Liquidity (Likuiditas)

- Perhitungan Loan to Deposit Ratio (LDR)

Likuiditas merupakan kemampuan bank untuk memenuhi kewajiban jangka pendeknya.

Tabel 11. Hasil Perhitungan Loan to Deposit Ratio (LDR) pada Bank BNI dan Bank BRI tahun 2011 - 2015

\begin{tabular}{ccccc}
\hline Nama Perusahaan & Tahun & $\begin{array}{c}\text { Total Kredit (Jutaan } \\
\text { Rupiah) }\end{array}$ & $\begin{array}{c}\text { Total DPK (Jutaan } \\
\text { Rupiah) }\end{array}$ & LDR (\%) \\
\hline & 2011 & $158,164,743$ & $224,755,289$ & 70.37 \\
PT. Bank Negara & 2012 & $193,016,854$ & $248,992,835$ & 77.52 \\
Indonesia (BNI) & 2013 & $239,363,451$ & $280,612,823$ & 83.3 \\
& 2014 & $262,577,901$ & $299,021,042$ & 87.81 \\
& 2015 & $326,105,000$ & $370,720,000$ & 87.97 \\
\hline PT. Bank Rakyat & 2011 & $28,586,497$ & $372,148,122$ & 76.81 \\
Indonesia (BRI) & 2012 & $348,231,964$ & $436,098,085$ & 79.85 \\
& 2013 & $430,621,874$ & $486,366,371$ & 88.54 \\
& 2014 & $490,410,064$ & $600,404,370$ & 81.68 \\
& 2015 & $581,094,544$ & $668,995,379$ & 86.86 \\
\hline
\end{tabular}

Sumber: data diolah Mei 2017 
Rasio LDR dikatakan sehat jika berada pada $<94,75 \%$. Dari hasil perhitungan diatas menunjukkan bahwa kedua bank memperoleh predikat SEHAT, karena hasil yang diperoleh $<94,75 \%$ hal tersebut menyatakan bahwa masing - masing bank mampu memberikan jaminan atas setiap simpanan yang diberikan nasabahnya dan memiliki kemampuan dalam membayar semua hutang berupa tabungan, giro dan deposito pada saat ditagih atau mampu melunasinya tepat waktu.

\subsection{Pembahasan}

Dari hasil perhitungan menggunakan rasio keuangan berupa CAR, KAP, NPM, ROA, BOPO, dan LDR dari tahun 2011-2015 menyatakan bahwa bank BNI dan bank BRI mendapat predikat SEHAT. Namun bank BRI lebih unggul dalam peningkatan nilai tiap tahunnya pada rasio CAR, KAP, NPM, ROA dan BOPO, sedangkan bank BNI hanya unggul pada rasio LDR saja.

Tabel 12. Perhitungan Kinerja Keuangan dengan Menggunakan Metode CAMEL pada Bank BRI dan Bank BNI periode 2011 - 2015

\begin{tabular}{cccccccc}
\hline Nama Bank & Tahun & CAR & KAP & NPM & ROA & BOPO & LDR \\
\hline & 2011 & $17.63 \%$ & $1.52 \%$ & $22.32 \%$ & $2.77 \%$ & $73.42 \%$ & $70.37 \%$ \\
Bank Negara & 2012 & $16.66 \%$ & $3.34 \%$ & $23.61 \%$ & $2.85 \%$ & $70.99 \%$ & $77.52 \%$ \\
Indonesia (BNI) & 2013 & $15.09 \%$ & $2.55 \%$ & $26.57 \%$ & $3.27 \%$ & $67.17 \%$ & $83.30 \%$ \\
& 2014 & $16.22 \%$ & $2.38 \%$ & $25.03 \%$ & $3.33 \%$ & $69.78 \%$ & $87.81 \%$ \\
& 2015 & $19.49 \%$ & $2.73 \%$ & $25.91 \%$ & $2.25 \%$ & $75.29 \%$ & $87.97 \%$ \\
\hline & 2011 & $14.96 \%$ & $2.68 \%$ & $28.53 \%$ & $4.73 \%$ & $66.69 \%$ & $76.81 \%$ \\
Bank Rakyat & 2012 & $16.95 \%$ & $2.14 \%$ & $33.02 \%$ & $4.93 \%$ & $59.93 \%$ & $79.85 \%$ \\
Indonesia (BRI) & 2013 & $16.99 \%$ & $1.95 \%$ & $32.25 \%$ & $4.97 \%$ & $60.58 \%$ & $88.54 \%$ \\
& 2014 & $18.31 \%$ & $2.45 \%$ & $29.64 \%$ & $4.59 \%$ & $65.37 \%$ & $81.68 \%$ \\
& 2015 & $20.59 \%$ & $2.34 \%$ & $34.75 \%$ & $3.69 \%$ & $67.96 \%$ & $86.86 \%$ \\
\hline
\end{tabular}

\section{KESIMPULAN DAN SARAN}

\subsection{Kesimpulan}

Analisis dengan metode CAMEL (Capital, Assets, Management, Earnings, Liquidity) pada Bank Umum Milik Negara yaitu bank Bank Negara Indonesia dan bank Bank Rakyat Indonesia pada tahun 2011 - 2015 dapat disimpulkan bahwa: Bank Negara Indonesia dan Bank Rakyat Indonesia dinilai SEHAT, karena berdasarkan perhitungan nilai kedua bank berada pada predikat SEHAT, namun bank BRI lebih unggul dalam menunjukkan prestasi peningkatan pada rasio CAR, KAP, NPM, ROA, BOPO dibanding dengan bank BNI yang unggul hanya pada rasio LDR. Dengan demikian kedua bank ini dinyatakan memiliki ketahanan yang baik dalam menghadapi gejolak perekonomian saat ini.

\subsection{Saran}

Berdasarkan hasil penelitian dan kesimpulan yang telah diuraikan, maka peneliti menyarankan sebagai berikut:

a. Sebaiknya bank lebih memperhatikan Kualitas Aktiva Produktif yang terlalu tinggi, karena menyebabkan Kualitas Aktiva Produktif yang Diklasifikasikan pun dinilai terlalu tinggi. Saat Aktiva Produktif yang Diklasifikasikan terlalu tinggi maka bank tersebut akan mendekati posisi predikat yang tidak sehat.

b. Untuk peneliti selanjutnya agar objek yang diteliti dapat ditambah, sehingga lebih mudah dalam membandingkan kinerja keuangan suatu bank. 


\section{DAFTAR PUSTAKA}

Bank Rakyat Indonesia (BRI) (www.bri.co.id)

Bank Negara Indonesia (BNI) (www.bni.co.id)

Bursa Efek Indonesia (www.idx.co.id)

Darmawi Herman, 2011. Manajemen Perbankan. Penerbit Bumi Aksara. Jakarta

Dendawijaya Lukman, 2009. Manajemen Perbankan. Jakarta: Ghalia Indonesia.

Fahmi Irham, 2014. Analisis Kinerja Keuangan. Penerbit Alfabeta. Bandung

Hery, 2016. Analisis Laporan Keuangan. Penerbit PT Gramedia Widiasarana Indonesia. Jakarta

Ikatan Akuntan Indonesia (IAI). Standar Akuntansi Keuangan (SAK) perefektif 1 Januari 2015

Jacob Jeremiah Kevin Dennis, 2013. Analisis Laporan Keuangan Dengan Menggunakan Metode CAMEL Untuk Menilai Tingkat Kesehatan Perbankan. Jurnal EMBA 691 Vol.1 No.3 September 2013, ISSN 2303-1174. URL: https://ejournal.unsrat.ac.id/index.php/emba/article/download/2137/1698

Kasmir, 2014. Bank dan Lembaga Keuangan Lainnya. Penerbit PT Raja Grafindo. Jakarta Kasmir, 2012. Bank dan Lembaga Keuangan Lainnya. Penerbit Rajawali Pers. Jakarta Pandia Frianto. 2012. Manajemen Dana dan Kesehatan Bank. PT Rineka Cipta.

Yoviani Fitria, 2016. Perbandingan kinerja keuangan dengan menggunakan metode CAMEL pada PT Bank Negara Indonesia, Tbk. Dan entitas anak dengan PT Bank Internasional Indonesia, Tbk dan entitas anak. Jurnal FinAcc, vol 1, No 7, Nopember 2016. URL: https://journal.widyadharma.ac.id/index.php/finacc/article/view/350 